\title{
RMB Exchange Rate and China's Economic Growth: The Empirical Analysis from a Structural VAR Model
}

\author{
Cancan $\mathrm{Su}^{1} \& \mathrm{Jia} \mathrm{Wu}^{1}$ \\ ${ }^{1}$ Departmentl of Economics, Jinan University, Guangzhou, China \\ Correspondence: Jia Wu, Department of Economics, Jinan University, Guangzhou, 601 Huangpu Avenue West, \\ China. Tel: 86-156-2605-8656. E-mail: jwu@jnu.edu.cn
}

Received: May 7, 2017

Accepted: May 29, 2017

Online Published: June 20, 2017

doi:10.5539/ijef.v9n7p189

URL: https://doi.org/10.5539/ijef.v9n7p189

\begin{abstract}
This paper analyzes the relationship between the exchange rate and the real GDP of China in the long period from 1952 to 2014 using a structural VAR model. We examine the mutual effect of the two variables in three periods: The results show that there is no obvious relationship between the exchange rate and real GDP before China's reform and opening-up period. However, a significant positive correlation is found in the sample of 1979-1993, which means that the depreciation of the RMB is associated with the output increases. The direction between the exchange rate and real GDP becomes negative after 1994, indicating that RMB appreciates with the output increases in this period. In addition, based on Granger causality test, we found the exchange rate could Granger causes GDP after 1978, but there is no Granger causality connection between the two variables before 1978.
\end{abstract}

Keywords: RMB exchange rate, economic growth, bivariable analysis, structural VAR model

\section{Introduction}

The international monetary fund (IMF) passed a decision to include the RMB into the special drawing right (SDR) basket on 30 November 2016. This is an important milestone of China to enter the global financial system. China's foreign trade will hopefully be more active and it's cross-border consumption will predictably increase. In the Mundell model the exchange rate, the monetary policy and the free flow of capital are strictly connected. Because the monetary policy and the capital flows are both reflected in the exchange rate, the exchange rate becomes the central issue of RMB internationalization (Salvatore, 2004). RMB internationalization requires the government relax controls for the forex, which means the RMB exchange rate will be determined by market supply and demand.

At the same time, China's economic growth is slowing down in recent years. There is a trade-off between the process of the RMB exchange rate internationalization and steady growth of economy because exchange rate is like of a "double-edged sword" that may stimulate or impede the economic growth. On the one hand, low exchange rate may stimulate the economic growth because the RMB exchange rate internationalization can improve the international competitiveness. On the other hand, exchange rate may impede the economic growth because high foreign exchange reserves have negative influence on the steady growth of economy. If the relationship between the exchange rate and the output are not well understood, the improper policy may induce the instability of China's economy. However, yet to date the literature is silent on the linkage between the exchange rate and the output. The disputation ranges from the causal effect between the two variables to the sign of the relationship between them (see Kiguel \& Liviatan, 1992; Dornbusch, 1988). Further, the lack of long-term historical Chinese data makes it to be a tough question for scholars to understanding Chinese situation. In this paper, we analyze the relationship between the exchange rate and the real GDP of China in the long period from 1952 to 2014 using a structural VAR model. We contribute to the existing literature from the following two points. First, combined with China's policy background, the long-run analysis on this issue makes our results be more convincing and be with high reference value for policy makers. Second, our structural VAR model incorporates the endogenous variables such as interest rate, inflation rate, balance of payments and government budget deficits. It allows us to portray the transmission mechanism between the exchange rate and the output. In addition, our model also incorporates exogenous variables, such as the US interest rate and the international oil price shock. It makes our model to be very close to the realistic situation. The findings show that there is no 
obvious relationship between the exchange rate and the real GDP before China's reform and opening-up period. In this period, China maintains the fixed exchange rate regime. However, a significant positive relationship is found in the sample of 1979-1993, which means that the depreciation of the RMB is associated with the output increases. The direction between the exchange rate and the real GDP becomes negative in the sample of 1994-2014, indicating that the RMB appreciates with the output increases in this period. In the research on the causal relationship of the exchange rate and the output, based on Granger causality test, we found the exchange rate could Granger causes GDP after 1978, but there is no Granger causality connection between the two variables before 1978 .

The remaining sections are organized as follows. In section 2, we review the literatures that study the connection between the exchange rate and the output. Section 3 provides a brief discussion of our data. Section 4 presents the empirical results, including bivariable analysis and structural VAR model analysis. Section 5 concludes the paper.

\section{Literature Review}

The link between exchange rate and output has been one of the controversial topics. There are two aspects scholars focus on: First, the causal relationship between the two variables: Whether the exchange rate movement affects the output or the output affects the exchange rate. Second, the direction between the two variables: Is the exchange rate appreciation or devaluation associated with the output increase. Scholars did a lot of research on the two problems, but there isn't a consistent conclusion.

For the connection between the exchange rate and GDP, Galvoet al. (1993) and Kamin (1996) argue that output influences the exchange rate because of the arbitrage theory. However, others believe that economy is often affected by the exchange rate. For example, Cline (1989) argues that the main reason lead to the international debt crisis is the appropriate exchange rate policy. Edwards (1988) maintains that the stability of the exchange rate is one of the factors to promote the economic growth in development countries. Kaminsky et al. (1998) find that persistent overvaluation is one of the important indicators to predict currency crises. Razin and Collins (1997) summarize that real exchange rate affects economic growth through trade and capital accumulation.Cottani et al. (1990) consider that exchange rate is the bond between policy and economic growth. Concretely, a stable exchange rate policy can promote economic growth; frequent changes of exchange rate will increase uncertainty of the expected prices, and the uncertainty of the expected prices will increase the risk of economic operation. Copelman and Werner (1996) find that devaluation depresses the level of output because devaluation causes inflation and interest rate rise. Specifically, on the one hand, the occurrence of inflation can reduce the confidence of investors; On the other hand, the interest rate rise can increase the risk of default. These two shocks will significantly reduce credit availability and depress the level of output. Cooper (1971) believes that currency devaluation leads to the decline in output in the period of payments deficit because devaluation can increase the foreign currency value.

What's more, for the direction between the exchange rate and GDP, Dornbusch (1988) believes that the exchange rate positive related to the output based on the theory of exchange rate depreciation stimulate exports. Other scholars reach a similar conclusion through the empirical research (see Edwards, 1988; Cottani et al., 1990; Ghura \& Grennies, 1993; Domac \& Shabsigh, 1990; Razin \& Collins, 1997). However, many scholars hold the opposite view that the exchange rate and output has a negative correlation. Krugman and Taylor (1978) find that devaluation will lead to economic contraction. Agenor (1991) regresses output growth on real exchange rate and expected real exchange rate by time series method, he finds that currency devaluation can reduce output after the government spending, money supply and income are controlled. But expected devaluation increases the output. Morley (1992) finds that currency devaluation can reduce output after the terms of trade, import growth, money supply and fiscal deficits are controlled. From the perspective of historical experience, Edwards (1995) believes that keeping exchange rate at a lower level can lead to serious inflation. Edwards (1989a) finds hold the exchange rate, government spending and the terms of trade constant, devaluations tend to reduce the output. Rogers and Wang (1995) estimate a five-variable VAR model (the output, the government spending, the inflation, the real exchange rate and the money growth), They find that positive shocks to the real exchange rate do lead to declines in the output.

\section{Data}

Our primary data sources are collected from the Penn World Tables 9.0 and the World Bank. Penn World Tables 9.0 includes macro data from 1952 to 2014 . We collect real per capita, GDP and the real exchange rate from this dataset. The rate of inflation, U.S. interest rate, China's interest rate, money supply (M2), current account and the international oil price data are taken from the World Bank. The variables are listed below: 
Real exchange rate: including China's real exchange rate and US real exchange rate, which are measured by direct quotation and are taken logarithm.

Real GDP: measured by constant prices of China's GDP in 2005, which is detrended and is taken logarithm.

Inflation rate: log-change in level of China's GDP deflator.

U.S. interest rates: the nominal loan interest rate (Note 1)in the United States, which is used to be the proxy for the world interest rates.

Interest rates: the nominal loan interest rates in China.

$M 2$ :the ratio of M2 to GDP.

Current account: the ratio of current account to GDP.

The international oil prices: log of the price of crude oil and petroleum products.

Table 1 shows the available data period from our data sources, " $\sqrt{ }$ "means the data is available in the corresponding period (Note 2).

Table 1. Summary statistics

\begin{tabular}{|c|c|c|c|c|c|}
\hline variables & First stage & $1952-1978$ & Second stage & 1979-1993 & Third stage 1994-2014 \\
\hline Exchange rate & $\sqrt{ }$ & & $\sqrt{ }$ & & $\sqrt{ }$ \\
\hline Real GDP & $\sqrt{ }$ & & $\sqrt{ }$ & & $\sqrt{ }$ \\
\hline Inflation rate & $\sqrt{ }$ & & $\sqrt{ }$ & & $\sqrt{ }$ \\
\hline Interest rate(U.S.) & $\sqrt{ }$ & & $\sqrt{ }$ & & $\sqrt{ }$ \\
\hline M2 & & & $\sqrt{ }$ & & $\sqrt{ }$ \\
\hline Current account & & & & & $\sqrt{ }$ \\
\hline Oil price & & & & & $\sqrt{ }$ \\
\hline VAR model & I & & I-II & & I-IV \\
\hline
\end{tabular}

Note." "means the data is available in the corresponding period. The last line in the table means the VAR model number.

Before our empirical analysis, we first test the stationarity on the above variables by unit root test, the results show that these variables are all I (1) process. Therefore, in the VAR analysis, all of these variables are used by their first difference.

Figure 1 depicts the relationship between the real exchange rate and the real GDP (Note 3). The solid line represents the real exchange rate and the dotted line represents the real GDP. The whole sample is divided into three sub-periods according to the Chow test. This test shows that the two variables have different slopes across different sub-periods.

As indicated in the Figure 1, the whole sample is divided into three sub-periods. The shadow in the figure is used to distinguished different sub-periods.

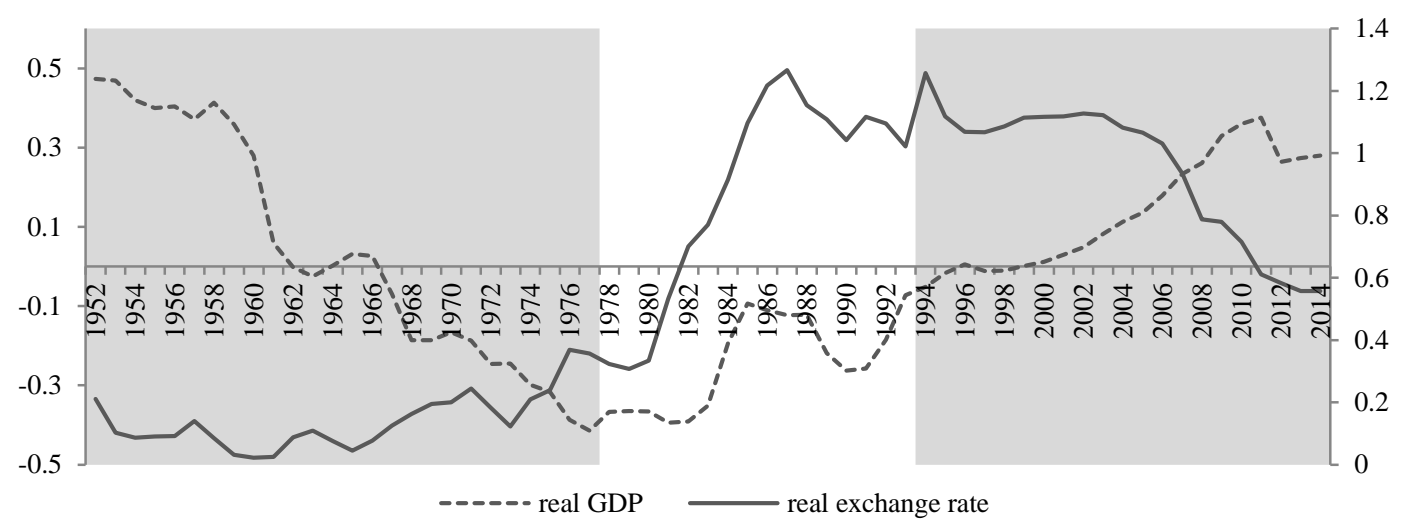

Figure 1. The real exchange rate and the real GDP

Figure 1 depicts the rough relationship between the real exchange rate and the real GDP, The diagram of "SalterSwann" in Figure 2 can sort out the various factors underlying the observed relationship between real exchange 
rate and output in China (see Salter, 1959; Swann, 1960). EB is the external balance curve which represents combinations of the real exchange rate and the output that equate the trade deficit with the capital account surplus. IB is the internal balance curve that represents the locus of points in which the supply of non-tradeable goods is equal to its demand.

Figure 2 uses Salter-Swan's diagram to fit our data. The figure shows that the relationship between the exchange rate and the income can bedivided into three stages. First, a weak negative relationship is found between the real exchange rate and the output before 1978.Next, the real exchange rate and the output show a strong positive relationship from 1978 to 1993. At last, the two variables reverse to be negatively associated from 1994 to 2014 . We will briefly analyze the results in each stage combined with China's policy.
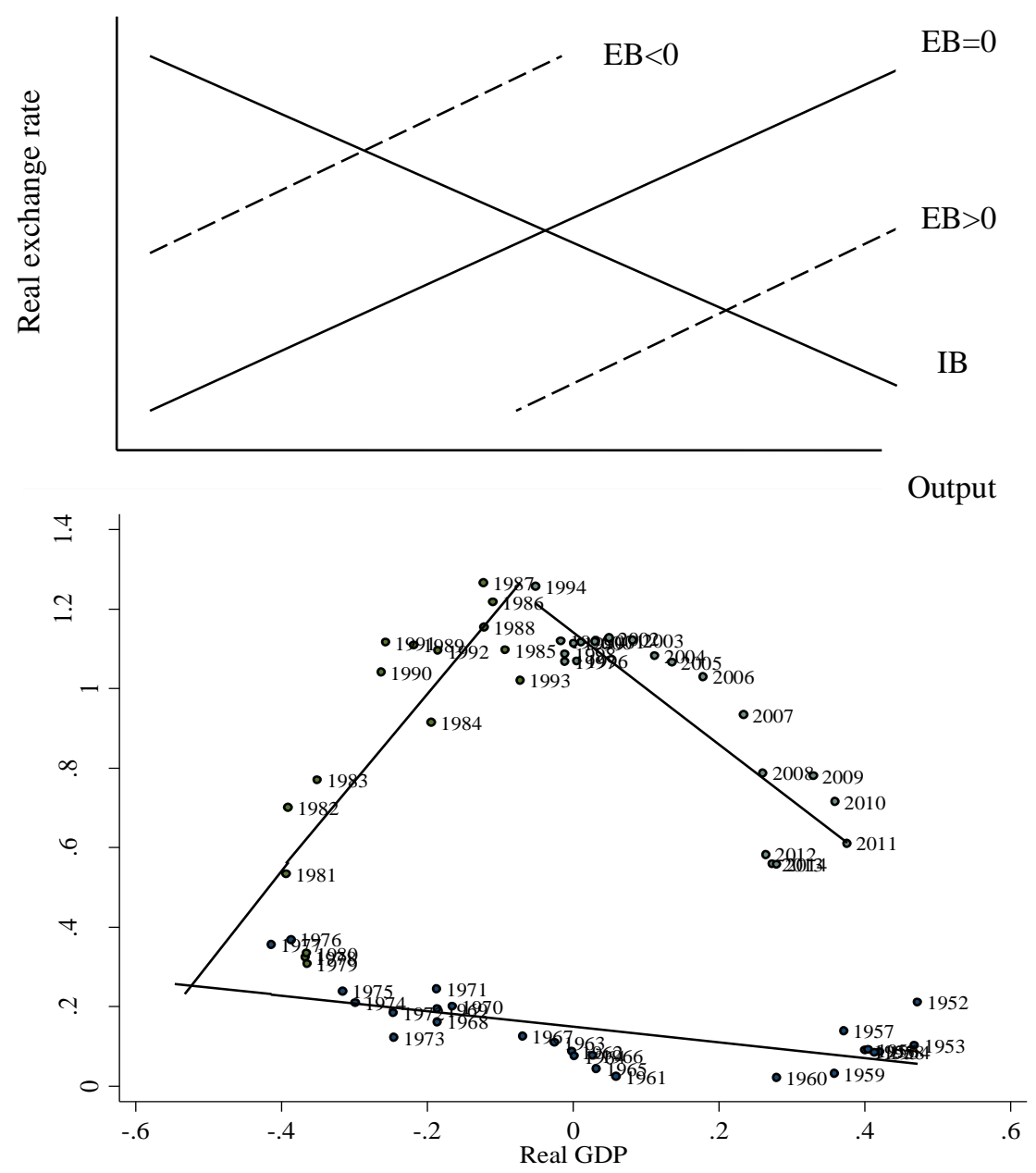

Figure 2. Real exchange rate vs. de-trended Real GDP

The First Stage (1952-1977). As indicated in Figure 2, the real GDP decreases (the lowest point in 1977)with the RMB currency depreciate in the first period. According to the theory of the Salter-Swann, the downward slope means that IB curve dominates. This is because China's economy is relatively closed in this stage. What's more, the decrease of income will reduces non-tradable goods consumption (because imports is rare in this stage), and causes the rise of the exchange rate and the depreciation of the RMB.

The Second Stage (1978-1993). Figure 2 shows that China's economy grows steady and the RMB devaluates rapidly in the second period. The upward slope means that EB curve has a dominant power. The possible reasons are listed as follows: First, the economy grows steady because the opening-up policy makes the number of tradable products increase. Second, the RMB devaluates rapidly because the stable population and the rising per capita income make the demand for imports increase.

The Third Stage (1994-2014). The figure shows that China's output is increasing with the appreciation of RMB in this period. It is means that IB curve has a dominant force. One possible explanation is that the growing 
demands for non-tradable goods(especially the development of the real estate industry and the tertiary industry). Another possible reason is that the rising of the domestic price level. Both of them would lead to the price of the non-tradable goods rising and the exchange rate declining.

\section{Empirical Results}

\subsection{Bivariate Data Analysis}

Based on Salter-Swann graphical analysis, we have a preliminary understanding about the relationship between China's exchange rate and GDP. In this section, we first analyze the correlations between the real exchange rate and output. We next study the causal relationship between the two variables based on the bivariate Granger causality tests.

Table 2 analyzes the correlations between the real exchange rate and the output using different lags of the two variables. $e$ is the real exchange rate, GDP is the detrended real GDP. The value in parentheses denotes the lag length, indicating that the number of quarters by which the real exchange rate is lagged relative to GDP. For the sample as a whole, the relationship between exchange rates and GDP seems to be ambiguous. We can not identify a consistent relationship between exchange rate and output. But for subsamples, the relationship is clear. In the sample of 1952-1978, there is a consistent negative relationship between the exchange rate and the output (Column 2). And the contemporary correlation coefficient is -0.662 . This means that the depreciation of the RMB is associated with the output decreases. The direction is different in the sample of 1979-1993, column 3 shows that the correlation coefficients are all positive. The contemporary correlation coefficient is 0.877 . It suggests that the depreciation of the RMB is associated with the output increases. In the sample of 1994-2014, the relationship between the exchange rate and the output becomes negative. And the contemporary correlation coefficient is -0.817 . This means that the appreciation of the RMB is associated with the output increases.

Table 2. Cross-correlations of GDP and the real exchange rate

\begin{tabular}{lcccc}
\hline & whole sample & $1952-1978$ & $1979-1993$ & $1994-2014$ \\
\hline$e(-4)$ & 0.356 & -0.095 & 0.046 & -0.094 \\
$e(-3)$ & 0.305 & -0.166 & 0.299 & -0.197 \\
$e(-2)$ & 0.242 & -0.321 & 0.572 & -0.327 \\
$e(-1)$ & 0.166 & -0.500 & 0.765 & -0.524 \\
0 & 0.081 & -0.662 & 0.877 & -0.817 \\
$G D P(-1)$ & 0.003 & -0.741 & 0.604 & -0.626 \\
$G D P(-2)$ & -0.067 & -0.718 & 0.407 & -0.524 \\
$G D P(-3)$ & -0.134 & -0.665 & 0.277 & -0.335 \\
$G D P(-4)$ & -0.199 & -0.624 & 0.172 & -0.186 \\
\hline
\end{tabular}

Note. The value in parentheses is the lag number length, indicating that the number of quarters by which the real exchange rate is lagged relative to GDP. For example: $G D P(-1)=\operatorname{corr}\left(G D P_{t-1}, e_{t}\right)$

To address the issue of directions between the real exchange rate and GDP, Table 3 presents the results of bivariate Granger causality tests (Note 4). $e$ denotes the null hypothesis that the real exchange rate cannot Granger causes the real GDP. GDP denotes the null hypothesis that the real GDP cannot Granger causes the real exchange rate. And the inspection includes 6 order lags of explanatory variables (Note 5).

Table 3. Granger causality tests: Real GDP and real exchange rate

\begin{tabular}{lcccc}
\hline & whole sample & $1952-1978$ & $1979-1993$ & $1994-2014$ \\
\hline $\mathrm{e}$ & $2.852^{* *}$ & 1.044 & $12.673^{* * *}$ & $4.847^{* *}$ \\
& $(0.021)$ & $(0.425)$ & $(0.002)$ & $(0.034)$ \\
GDP & 1.147 & 0.140 & 1.206 & 0.044 \\
& $(0.354)$ & $(0.964)$ & $(0.388)$ & $(0.995)$ \\
\hline
\end{tabular}

Note. $P$-values are in parentheses, *, **and $* * *$ show the significance level in $10 \%, 5 \%$, and $1 \%$.

For the sample as a whole, the F test for the null hypothesis "real exchange rate cannot Granger causes real GDP" is 2.852 , with a small $p$ value 0.021 . It means that the exchange rate change may be the Granger causality of the change of the real GDP. The F statistic corresponding to the null hypothesis that the real GDP cannot Granger causes the real exchange rate is 1.147 with $\mathrm{p}$ value 0.354 . Hence we cannot reject the null hypothesis. 
Column 2 to 4 show the results of Granger causality test between the real exchange rate and GDP in each of the sub-sample. For the first subsample (1952-1978), the result shows that the real GDP and the real exchange rate cannot Granger causes each other. Because the exchange rate is strictly controlledin this period, the RMB exchange rate can be set at any level. The results are consistent with the expectations.

During 1979-1993, the exchange rate regime is adjusted several times. In general, the characteristic of RMB exchange rate regime in this period is China uses the multiple exchange-rate criteria. Multiple exchange-rate criteria means the government separates the trade exchange rate from the capital exchange rate, and in this case, the capital exchange rate changes will not affect the trade exchange rate. The data show that the depreciation of RMB exchange rate every time in this period are all associated with the rising of exports (the result is not reported). Therefore, we might expect to see the real exchange rate causes the output. The Granger-causality results presented in the third column of Table 3 support our expectation. Specifically, the p value of the null hypothesis "the real exchange rate cannot Granger causes the real GDP" is 0.388 . We cannot reject the null hypothesis. But $\mathrm{P}$ value of the null hypothesis that real GDP cannot Granger causes the real exchange rate is 0.002. Small $\mathrm{p}$ value indicates the change of the real exchange rate may be the Granger causality of the change of the real GDP.

In the sub-sample of 1994-2014, though China experiences a rapid growth, it encounters several problems. Such as foreign trade imbalance, insufficient domestic demand and high inflation rate. Chinese government had to promote the exchange rate to overcome these issues. Therefore, it is difficult to determine the relationships between the exchange rate and GDP from intuition. Table 3 shows the direction of Granger causality test is from the real exchange rate to the real GDP in this period. The null hypothesis "the real exchange rate cannot Granger causes the real GDP" is rejected at the 5\% significant level. But the hypothesis that real GDP cannot Granger causes the real exchange rate can not be rejected at the usual level.

\subsection{VAR Analysis}

The bivariate analysis suggests that the exchange rate could Granger causes GDP after 1978. However, the bivariate analysis does not identify whether other existing variables affect the real exchange rate and GDP simultaneously. In this part, we will estimate a structural VAR model with fully controls for shocks from other variables.

Following Kamin and Rogers (2000), and combined with China's macroeconomic condition, we first include variables that should be correlated to our interest variables: the real GDP and the real exchange rate. Then we construct the illustrate model using the identified variables. After that, we specify the core VAR model based on the illustrate model. The illustrate model consist of 12 equations, a detailed description is as follows:

$$
Y=D+N E \text {. }
$$

Equation (1) divides GDP into domestic demand $D$ and net exports $N E$.

$$
N E=\gamma_{21} e-\gamma_{22} Y \text {. }
$$

Equation (2) says net export is positively related to the real exchange rate $\boldsymbol{e}$ and negatively related to the output $Y$. So the exchange rate increasing means depreciation of the domestic currency. The increased output stimulates the demand for the import and hence decreases the net exports.

$$
D=\gamma_{31} \text { deficit }+\gamma_{32} \text { credit }-\gamma_{33} \pi-\gamma_{34} e+\gamma_{35} \text { rwage }-\gamma_{36} r_{f} .
$$

We incorporate several factors that could affect the domestic demand: the fiscal deficit deficit, the stock of real bank credit credit, the rate of inflation $\pi$, the real exchange rate $e$, the real wage rwage and the nominal interest rate $r_{f}$.

On the one hand, Equation (3) says domestic demand positively related to the fiscal deficit, the stock of real bank credit and the real wage. The explanations are as follows: First, the increased government spending causes the increase in aggregate demand and leads to the deficit increase. Second, the increased amount of bank credit leads to the increase in output and domestic demand. Third, the increased real wage indicates that the improvement of people's income, therefore, leading to the increase in aggregate demand.

On the other hand, Equation(3) relates domestic demand negatively to the inflation rate $\pi$, the real exchange rate $e$ and the nominal interest rate $r_{f}$. This can be explained by the following theories: first of all, the increased inflation rate causes the increase in price level and leads to the aggregate demand increase. In addition, the increased interest rate raises the investment cost and lowers the demand for investment. Finally, since the positive effect of the real exchange rate on output is included in Equation(2), it is reasonable that any additional effects on domestic demand are negative. 


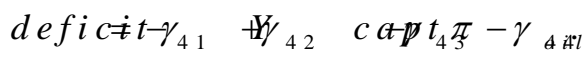

Equation(4) defines the determinant of government budget deficits. In the period of high inflation, government will take relatively tight fiscal policy to reduce the deficit. Positive Oil prices impact will causes the rise of domestic inflation and the inflation is negative related to the deficit. However, the increased net capital inflows will cause the increase in government loan and lead to the increase of fiscal deficit.

$$
\text { credit }=\gamma_{51} M_{2}+\gamma_{52} \text { capt. }
$$

Equation(5) relates the main sources of funds of bank credit credit, money supply $M_{2}$ and the net capital inflows capt.

$$
\pi=\gamma_{61} e+\gamma_{62} M_{2}+\gamma_{63} E .
$$

Equation(6) says that the inflation is determined by the real exchange rate $e$, the money supply $M_{2}$ and the nominal exchange rate $E$. All of them are positively related to the inflation rate. The depreciation of the nominal exchange rate will increase the prices of the tradeable goods in short terms (see Lizondo \& Montiel, 1989). Empirical evidences show that the depreciation of the real exchange rate will lead to higher inflation rate in the long run(see Edwards, 1989b; Calvo et al., 1994; Kamin, 1996). In addition, money supply will also lead to the higher inflation rate.

$$
e=-\gamma_{71} N E-\gamma_{72} \text { capt }
$$

We assume that the real exchange rate adjusts according to the balance of payments. Equation(7) states that the improvement in net exports or net capital inflows will lead to the appreciation of the real exchange rate.

$$
r w a g \in \gamma_{8}, Y \gamma_{8} \mathbb{I}
$$

Equation (8) says that the real wage positively depends on the output, however, negatively on the inflation rate.

$$
r_{f}=\gamma_{91} \pi+\gamma_{92} Y+\gamma_{93} \text { capt }
$$

Equation (9) says that the nominal interest rate is determined by the inflation rate, the output and the net capital inflows. The increased net capital inflows may lead to high inflation, and the government will raise interest rate in response. The increased output promotes the demand for money and causes the rise of the interest rate.

$$
\text { capt }=\gamma_{101} r_{f}-\gamma_{102} E-\gamma_{103} r_{U S} .
$$

Equation(10) is determined by the interest parity theory that the difference of the interest rate between the two countries should be equal to the difference between the forward rate and spot rate. The currency for high interest rate country will be discounted in the forward exchange rate market, whereas the country for low interest rate country will be with premium. $r_{U S}$ represents the exogenous US interest rate.

$$
M_{2}=\gamma_{111} Y-\gamma_{112} r_{f} \text {. }
$$

Equation(11) is a standard money demand equation. Money demandis positively related to the output, however, negatively related to the nominal interest rate.

$$
E=\gamma_{121} \pi-\gamma_{122} \pi_{U S}+\gamma_{123} e .
$$

Equation(12) is based on the definition of the real exchange rate: $e=P^{*} E / P, \pi_{U S}$ represents the inflation rate in the United States.

Based on the Equation (1) to Equation (12), we set the coefficients on the exogenous variables to zero (Note 6) and substitute all the endogenous variables by the inflation rate $\pi$, the exchange rate $e$, the output $Y$. Equation (1) to Equation (12) can be rewritten as follows:

$$
\begin{aligned}
& Y=-a_{11} \pi+a_{12} e-a_{13} r_{U S} \\
& \pi=a_{21} e+a_{22} Y \\
& e=a_{31} r_{U S}+a_{32} \pi+a_{33} Y .
\end{aligned}
$$

Equation(13) is the core VAR model. The model is identified by the Cholesky decomposition technique proposed by Sims(1980). In addition to the core model, we estimate a number of additional models (Note 7) as follows:

Model 1: US interest rate, real exchange rate, inflation rate, real GDP.

Model 2: US interest rate, real exchange rate, M2, real GDP.

Model 3: US interest rate, current account, real exchange rate, inflation rate, real GDP.

Model 4: Oil price, real exchange rate, inflation rate, real GDP. 
Figures 3 reports the impulse-response functions of the real GDP (Note 8). The figures show the responses of GDP to a one-time shock in each of the variables in the system. The horizontal line shows the lag period, and the vertical line is the response of GDP.

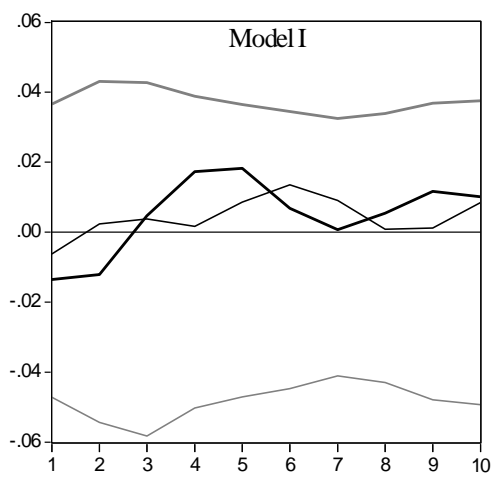

Panel A. (1952-1978)
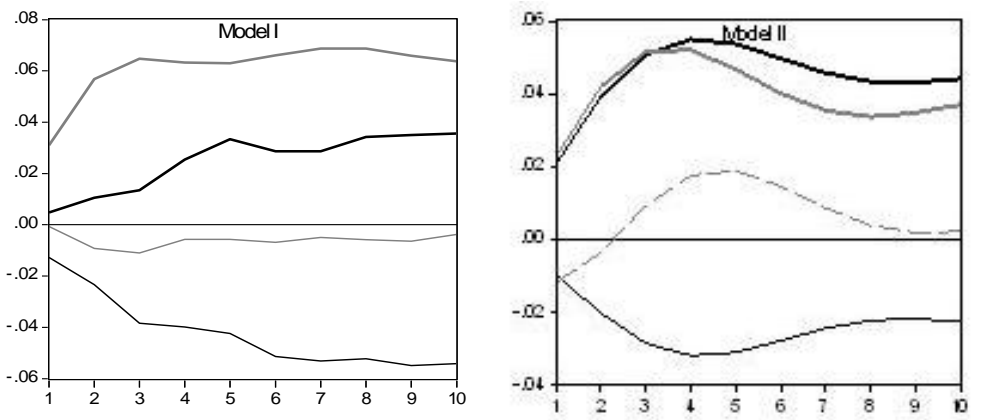

Panel B. (1979-1993)
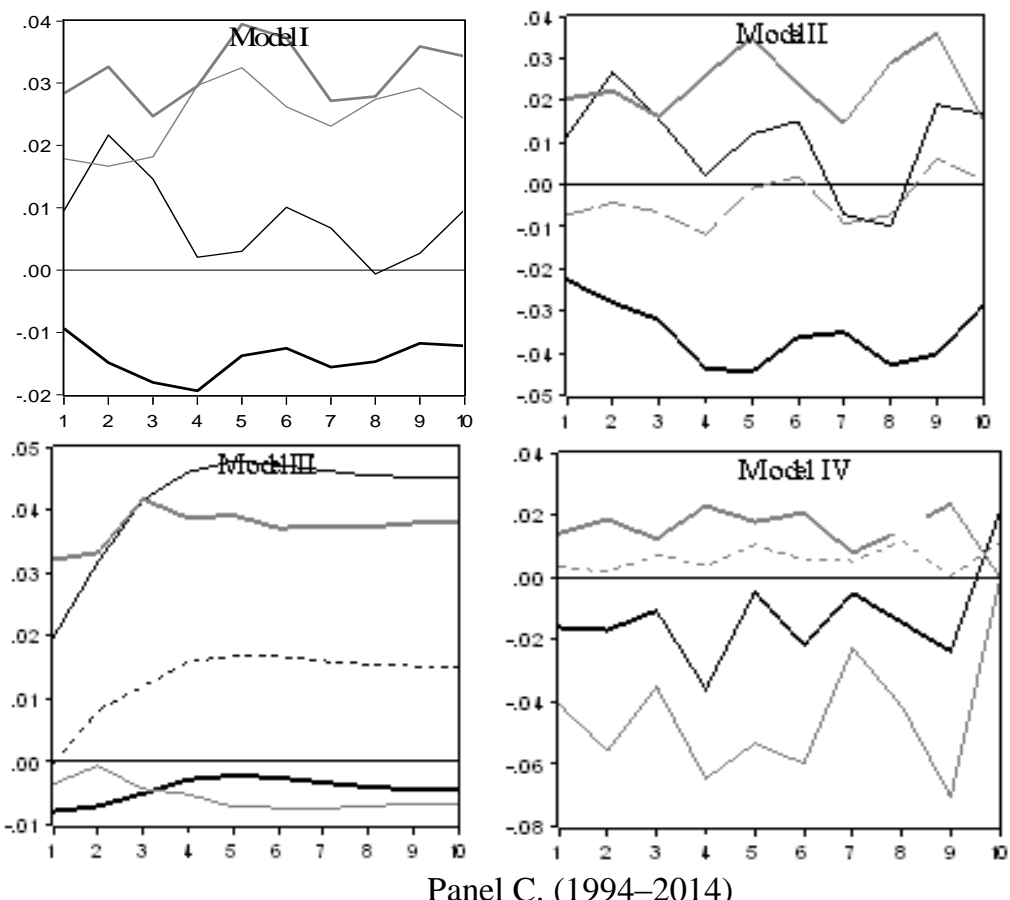

Figure 3. The impulse-responses of the real GDP

Note. This graph presents the impulse responses of the real GDP. Panel A, B and C represent results in different sub-periods. In the graph, the bold black line indicates the GDP response to the real exchange rate; the bold gray line indicates the GDP response to itself; the thin black indicates the GDP response to US interest rate; the thin gray line indicates the GDP response to inflation rate; the dash gray line indicates the GDP response to money supply; the black dot line indicates the GDP response to oil price. 
It is note that the one-time shock on variables of the first difference means the permanent shocks of its level. As the limitation of the early data, Panel A shows the graph of the impulse-response function of GDP estimated for the VAR model I from 1952-1978. First, we cannot find a consistent relationship between the exchange rate and the output in this panel. In particular, continuous positive impacts on the real exchange rate reduce the output in the first two periods, but lead to the increase of output in the third period. The effect reduces to zero in the seventh period. We also calculate the corresponding standard deviations of the estimate effect. It shows that the response of output to the real exchange rate shock is not statistically significant. Such result is consistent with the analysis of the above text. The reason is that the RMB exchange rate is strictly controlled by the government before the reform and opening up period. The determination of the exchange rate does not reflect the supply and demand of the forex, and it also does not affect the price level, import, export, and the output. In addition, Granger causality test shows that there is no Granger relationship between the two variables in this period. Second, a permanent shock from inflation leads to a persistent reduction in the level of the real GDP. The results are significant in the first four periods. From our intuition, the continuous inflation will cause a decline in output.

Panel B describes the graph of the impulse-response function of the real GDP from 1979-1993. We use model I and model II to estimate the coefficients in this period. We can get the following two conclusions. First, a permanent, positive shock to the level of the real exchange rate leads to a persistent increase of the level of the real GDP. It is suggested that the exchange rate is positively correlated to the real GDP. The standard deviation indicates that the coefficients are statistically significant at the first five periods. The results are consistent with the characteristics of China's economy in this period: First, the depreciation of the RMB promotes the development of the exports and hence leads to the increase of the output. Second, a permanent, positive shock from the level of the US interest rate leads to a persistent reduction in the level of the real GDP. Such results are consistently found when different VAR models are used. One possible explanation is that the higher US interest rate will attract foreign capital, which reduces China's domestic investment.

Panel C shows the graph of the impulse-response function of the real GDP from 1994-2014. And the sample is estimated by VAR models I-IV. Compared with results found in previous periods, it shows that a continuous positive shock from the level of the real exchange rate has persistent negative impact on the level of the real GDP. Such results are consistently found in models I-IV. Specifically, whether we include US interest rate or Oil price in the model, the real GDP and the real exchange rate are all negatively correlated in this period. Further, the small standard errors indicate that the coefficients are statistically significant at the first five periods.

\section{Conclusion}

This paper analyzes the connections between the real exchange rate and the real GDP of China in the long period from 1952 to 2014. The results show that there is no obvious relationship between the real exchange rate and the real GDP before China's reform and opening-up. However, a significant positive correlation is found in the sample of 1979-1993, which means that the depreciation of the RMB is associated with the increase of the output. The direction between the real exchange rate and the real GDP becomes negative after 1994, indicating that RMB appreciation is associated with the output increases. The inconsistent finding among different periods may be caused by the different economic policies implemented in the corresponding periods. In addition, based on Granger causality test, we found the exchange rate could Granger causes GDP after 1978, but there is no Granger causality between the two variables before 1978(The strict capital controls and closed economy environment in this stage make the two variables are uncorrelated).

However, though we found a negative relationship between economic growth and the exchange rate, we do not suggest stimulate economic growth through exchange rate manipulation. Because it may induce other related issues, for example: a high inflation in the long run. Based on our finding in this paper, two suggestions are proposed: First, the managed floating exchange rate system and China's economic development should be coordinated; Second, based on China's economic growth and the goal of the stable system of trade and currency exchange, a long-term planning of the reform of exchange rate mechanism should be set up.

\section{Acknowledgment}

The authors are grateful to the funding support provided by Guangzhou planning office of philosophy and social science (2017GZQN08).

\section{References}

Agenor, P. R. (1991). Output, Devaluation, and the Real Exchange Rate in Developing Countires. Welwirtschafftliches Archiv, 127, 18-41. https://doi.org/10.1007/bf02707309

Calvo, G., Reinhart, C., \& Vegh, C. A. (1994). Targeting the Real Exchange Rate: Theory and Evidence. IMF 
Working Paper 94/22. https://doi.org/10.5089/9781451921212.001

Cline, W. R. (1989). US External Adjustment and the World Economy. Washington: Institute for Internal Economics.

Cooper, R. N. (1971). Government and Economic Development. New Haven, Yale University.

Copelman, M., \& Werner, A. M. (1996). The Monetary Transmission Mechanism in Mexico. Federal Reserve Board Working Paper.

Cottani, J., Cavallo, D., \& Khan, S. (1990). RER Behavior and Economic Performance in LDCs. Economic Development and Culture Change, 39, 61-76. https://doi.org/10.1086/451853

Domac, L., \& Shabsigh, G. (1990). Real Exchange Rate Behavior and Economic Growth: Evidence from Egypt, Jordan, Morocco, and Tunisia. IMF Working Paper. https://doi.org/10.5089/9781451845952.001

Dornbusch, R. (1988). Open Economy Macroeconomics. New York: Basic Books. https://doi.org/10.1016/0164-0704(81)90098-7

Edwards, S. (1988). Real and Monetary Determinats of Real Exchange Rate Behavior: Theory and Evidence from Developing Countries. Journal of Development Economics, 29, 311-341. https://doi.org/10.1016/0304-3878(88)90048-X

Edwards, S. (1989a). Real Exchange Rates in Developing Countries: Concepts and Measurement. NBER Working Paper No. 2950. https://doi.org/10.3386/w2950

Edwards, S. (1989b). Real Exchange Rates, Devaluation, and Adjustment. Cambridge, MIT Press. https://doi.org/10.2307/2554662

Edwards, S.(1995), Public Sector Eeficits and Macroeconomic Stability in Developing Economies. NBER Working Paper, 307-373. https://doi.org/10.3386/w5407

Galvo, G. A., \& Vegh, C. A. (1993). Open-Economy Macroeconomics. Lodon: McMillan.

Ghura, D., \& Grennies, T. (1993). The RER and Macroeconomic Performance in Sub Saharan Africa. Journal of Development Economics, 42, 155-174. https://doi.org/10.1016/0304-3878(93)90077-Z

Kamin, S. B. (1996). Exchange Rates and Inflation in Exchange-Rate Based Stabilizations: An Empirical Examination. International Finance Discussion Paper. https://doi.org/10.1016/s0304-3878(00)00131-0

Kamin, S. B., \& Rogers, J. H. (2000). Output and the Real Exchange Rate in Developing Countries: An Application to Mexico. Journal of Development Economics, 61(1), 85-109. https://doi.org/10.1016/S0304-3878(99)00062-0

Kaminsky, G., Lizondo, S., \& Reinhart, C. M. (1998). Leading Indictators of Currency Criscs. IMF Staff Papers, 45(1), 1-48. https://doi.org/10.2307/3867328

Kiguel, M. A., \& Liviatan, N. (1992). Stopping Three Big Inflations. Washington, D.C.: Country Economics Dept., World Bank.

Krugman, P., \& Taylor, L. (1978). Contractionary Effects of Devaluation. Journal of International Economics and Finance, 8, 445-456. https://doi.org/10.1016/0022-1996(78)90007-7

Lizondo, S., \& Montiel, P. J. (1989). Contractionary Devaluation in Developing Countries: An Analytical Overview. IMF Staff Papers, 36, 182-227. https://doi.org/10.2307/3867174

Morley, S. A. (1992). On the Effect of Devaluation During Stabilization Programs in LDs. Review of Economics and Statistic, 74(1), 21-27. https://doi.org/10.2307/2109538

Razin, O., \& Collins, S. M. (1997). Real Exchange Rate Misaligment and Growth. NBER Working Paper No. 6174. https://doi.org/10.3386/w6174

Rogers, J. H., \& Wang, P. (1995). Output, Inflation, and Stabilization in a Small Open Economy: Evidence from Mexico. Journal of Development Economics, 46, 271-293. https://doi.org/10.1016/0304-3878(94)00064-j

Salter, W. E. (1959). Internal and External Balance: The Role of Price and Expenditure Effects. Economic Record, 35, 226-238. https://doi.org/10.1111/j.1475-4932.1959.tb00462.x

Salvatore, D. (2004). Introduction to International Economics. John Wiley and Sons. https://doi.org/10.4324/9780203462041_chapter_1

Sims, C. A. (1980). Macroeconomics and Reality. Econometrica, 48, 1-48. https://doi.org/10.2307/1912017 
Swann, T. (1960). Economic Control in a Dependent Economy. Economic Record, 36, 51-66. https://doi.org/10.1111/j.1475-4932.1960.tb00493.x

\section{Notes}

Note 1 . We chose the loan interest rate because China's early interest rate on deposit is not obtained. And the analysis of the sample data suggests that the loan interest rate is consistent with the deposit interest rate.

Note 2. Due to some early sample data is unable to get, so not all the stages can be estimated in the above four extension model.

Note 3. The data of real exchange rate and real GDP are from Penn World Tables 9.0.

Note 4 . Before the Granger causality test, the unit root test suggests that the differences of the two variables are stable.

Note 5. The 4 order lag Granger causality test is also contained in this paper, and the results are in accordance with table 3.

Note 6. The coefficient of US interest rate is not set to 0, because Eq. (7) and Eq. (10) show that US interest rate has a decisive impact on the real exchange rate.

Note 7. Due to some early sample data is unable to get, so not all the stages can be estimated in the above four extension model. The details has showed in the table 1.

Note 8. Because the Granger causality tests indicates that the direction of causality is from the real exchange rate to real GDP in most stages (in the first stage of sample the direction of causality is not clear), so we only analyze the impulse response function of GDP.

\section{Copyrights}

Copyright for this article is retained by the author(s), with first publication rights granted to the journal.

This is an open-access article distributed under the terms and conditions of the Creative Commons Attribution license (http://creativecommons.org/licenses/by/4.0/). 